\title{
STRATEGI PEMERINTAH DALAM MENGHADAPI REVOLUSI INDUSTRI 4.0 : HAKI
}

\author{
DEVI RISTA \\ NPM 155100019, KDV 785567831 \\ Fakultas Komputer \\ Devirista.student@umitra.ac.id
}

\begin{abstract}
Kemajuan teknologi dalam revolusi industri generasi ke-4 ini mengalami terobosoan luar biasa. Untuk dapat bersaing dalam era revolusi industri generasi ke-4 ini kita perlu meningkatkan kemampuan bangsa dalam mengembangkan keunggulan teknologi yang kompetitif dan mengembangkan kreatifitas yang berbasis pada kekayaan intelektual khusus paten. Pengembangan sistem paten di Indonesia tidaklah semata-mata karena tekanan dunia internasional, namun juga karena kebutuhan nasional untuk menciptakan suatu sistem perlindungan paten yang efektif dan juga bermanfaat bagi bangsa Indonesia. Perangkat hukum dibidang paten diperlukan untuk memberikan perlindungan hukum dan mewujudkan suatu iklim yang lebih baik bagi kegiatan invensi teknologi serta mempermudah masuknya teknologi ke dalam negeri. Untuk memperlancar tujuan itu semua maka perlu di dilakukan pembaharuan sistem paten diantaranya: ketentuan pengungkapan yang cukup (sufficient disclosure), ketentuan pengecualian terhadap hak eksklusif paten, ketentuan lisensi paten, ketentuan lisensi wajib paten, dan sistem pelayanan informasi paten.

Revolusi Industri 4.0 Adalah Prof Klaus Schwab, Ekonomi terkenal dunia asal Jerman, Pendiri dan Ketua Eksekutif World Economic Forum (WEF) yang mengenalkan konsep Revolusi Industri 4.0. Dalam bukunya yang berjudul

"The Fourth Industrial Revolution", Prof Schawab (2017) menjelaskan revolusi industri 4.0 telah mengubah hidup dan kerja manusia secara fundamental.

Revolusi industri saat ini memasuki fase keempat. Perkembangan ilmu pengetahuan dan teknologi yang sangat pesat memberikan dampak yang besar terhadap kehidupan manusia. Banyak kemudahan dan inovasi yang diperoleh dengan adanya dukungan teknologi digital.
\end{abstract}

Kata kunci: paten, invensi, teknologi, hak eksklusif, lisensi wajib 


\section{A. INTRODUCTION}

Apa itu Revolusi Industri 4.0?

Revolusi Industri 4.0 Adalah

Prof Klaus Schwab, Ekonomi terkenal dunia asal Jerman, Pendiri dan Ketua Eksekutif World Economic Forum (WEF) yang mengenalkan konsep Revolusi Industri 4.0. Dalam bukunya yang berjudul

"The Fourth Industrial Revolution", Prof Schawab (2017) menjelaskan revolusi industri 4.0 telah mengubah hidup dan kerja manusia secara fundamental. Berbeda dengan revolusi industri sebelumnya, revolusi industri generasi ke-4 ini memiliki skala, ruang lingkup dan kompleksitas yang lebih luas. Kemajuan teknologi baru yang mengintegrasikan dunia fisik, digital dan biologis telah mempengaruhi semua disiplin ilmu, ekonomi, industri dan pemerintah. Bidang-bidang yang mengalami terobosan berkat kemajuan teknologi baru diantaranya (1) robot kecerdasan buatan (artificial intelligence robotic), teknologi nano, bioteknologi, dan (4) teknologi komputer kuantum, blockchain (seperti bitcoin), (6) teknologi berbasis internet, dan (7) printer $3 \mathrm{D}$.

Ekonomi global saat ini sedang pada titik puncak perubahan besar yang sebanding besarnya dengan munculnya revolusi industri pertama atau perkembangan perakitan produksi, atau bahkan penemuan mikrocip. Kemajuan teknologi memungkinkan terjadinya otomatisasi hampir di semua bidang. Sementara itu, kepemilikan perangkat pintar di berbagai bagian dunia mengarah pada tingkat keterkaitan satu sama yang lain yang tak terbayangkan sebelumnya. Di antara berbagai tantangan yang sedang dihadapi dunia saat ini, mungkin yang paling besar adalah bagaimana membentuk Revolusi Industri keempat (disebut juga sebagai Industri 4.0) yang dimulai pada permulaan abad ini.

Teknologi dan pendekatan baru yang menggabungkan dunia fisik, digital, dan biologi dengan cara yang fundamental akan mengubah umat manusia. Ada banyak pendapat bahwa sektor kesehatan dan bioteknologi sangat diuntungkan oleh transformasi ini. Sejauh mana transformasi ini akan berdampak positif bergantung pada

bagaimana kita menavigasi risiko dan peluang yang muncul di sepanjang jalan. Saat ini kita berada di ambang revolusi teknologi yang secara fundamental akan mengubah cara kita hidup, bekerja, dan berhubungan satu sama lain. Dalam skala, ruang lingkup, dan kompleksitasnya, transformasi yang sedang terjadi berbeda dengan apa yang telah dialami manusia sebelumnya. 
B. CONTENT

STUDI REFERENSI

Pada Bagian Introduction sudah dijelaskan mengenai awal mula revolusi industri.

Revolusi industri 4.0 akan membawa perubahan besar dalam dunia industri nasional.

Dirilisnya peta jalan "Making Indonesia 4.0" menjadi tanda bahwa pemerintah serius dan siap membawa Indonesia menuju Industri 4.0.

Berdasarkan Global Competitiveness Report 2017, posisi daya saing Indonesia berada di peringkat ke-36 dari 100 negara. Walaupun telah naik sebesar 5 peringkat dibandingkan tahun sebelumnya, pemerintah merasa perlu melakukan perubahan secara sistematis dan menerapkan strategi untuk berkompetisi.

Menurut Menteri Perindustrian Airlangga Hartanto, dirilisnya peta jalan industri 4.0 merupakan salah satu cara untuk mencapai aspirasi besar nasional, yakni membawa Indonesia menjadi 10 besar kekuatan ekonomi dunia pada 2030, mengembalikan angka net export industri 10 persen, peningkatan produktivitas tenaga kerja hingga dua kali lipat dibanding peningkatan biaya tenaga kerja, serta pengalokasiaan 2 persen GDP untuk R\&D teknologi dan inovasi.
Untuk mencapai hal tersebut, pemerintah telah menyiapkan 10 langkah prioritas nasional untuk mengimplementasikan peta jalan

"Making Indonesia 4.0".

"Dirilisnya peta jalan ini memudahkan kita untuk mencapai target nasional sehingga kita sudah memiliki arah yang jelas. Ada 10 langkah prioritas nasional yang akan kita terapkan," ujarnya di acara Obsat ke-202 $(11 / 5 / 2018)$.

Langkah pertama yang akan diambil adalah memperbaiki alur aliran material sehingga dapat memperkuat produksi material sektor hulu melalui peningkatan kapasitas dan percepatan adopsi teknologi.

Kedua, pemerintah akan membangun peta jalan zona industri nasional untuk dapat menyelesaikan masalah yang dihadapi beberapa zona industri.

Ketiga, pemerintah akan mengakomodasi standar keberlanjutan, contohnya industri berbasis teknologi bersih, biokimia, dan energi terbarukan.

"Keempat, kita akan mendorong UMKM yang kita sebut enabler. Jadi kalau dulu korporasi itu yang berkumpul yang punya modal dan 
membentuk PT. Tapi di ekonomi digital yang bergabung adalah orang per orang, ini persis seperti koperasi," tutur Airlangga.

Kelima, kata Airlangga, pemerintah akan membangun infrastruktur digital nasional. Prioritasnya adalah pembangunan jaringan internet berkecepatan tinggi dan platform digital yang dapat memuluskan transisi menuju industri 4.0.

Langkah keenam adalah dengan menarik investasi asing. Pemerintah menargetkan perusahaan manufaktur terkemuka global melalui penawaran yang baik serta insentif untuk mendorong percepatan transfer teknologi ke perusahaan lokal.

Ketujuh, pemerintah akan meningkatkan kualitas sumber daya manusia dengan meningkatkan kualitas sekolah kejuruan serta mengubah kurikulum pendidikan agar sesuai dengan perubahan industri 4.0. Selanjutnya, pemerintah akan membentuk pusat ekosistem inovasi berupa sentra R\&D termasuk di dalamnya perlindungan hak atas kekayaan intelektual (HAKI).

Langkah kesembilan, pemerintah akan memberikan insentif untuk investasi teknologi, yaitu mendesain ulang rencana insentif adopsi teknologi. Sedangkan harmonisasi antara aturan dan kebijakan untuk mendukung revolusi industri 4.0 menjadi strategi terakhir yang akan diterapkan oleh pemerintah.

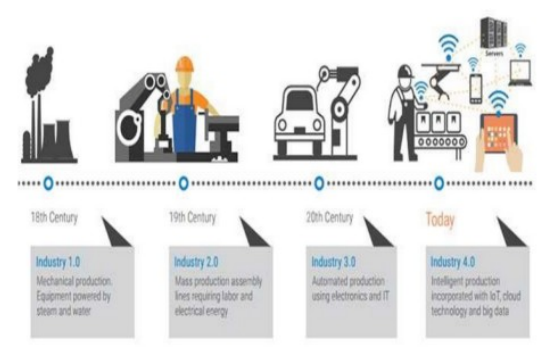

Gambar 1. Revolusi Industri 4.0

(Sumber: www.kompasiana.com)

\section{CONCLUSION}

Kesimpulan dari artikel ini adalah Revolusi industri saat ini memasuki fase keempat. Perkembangan ilmu pengetahuan dan teknologi yang sangat pesat memberikan dampak yang besar terhadap kehidupan manusia. Banyak kemudahan dan inovasi yang diperoleh dengan adanya dukungan teknologi digital. Layanan menjadi lebih cepat dan efisien serta memiliki jangkauan koneksi yang lebih luas dengan sistem online. Hidup menjadi lebih mudah dan murah. Namun demikian, digitalisasi program juga membawa dampak negatif. Peran manusia setahap demi setahap diambil alih oleh mesin otomatis. Akibatnya, jumlah pengangguran semakin meningkat. Hal ini tentu saja 
akan menambah beban masalah lokal maupun nasional. Oleh karena itu, untuk memanfaatkan peluang dan menjawab tantangan

revolusi industri 4.0, para mahasiswa dan alumni Universitas Terbuka wajib memiliki kemampuan literasi data, teknologi dan manusia.

\section{DISCUSSION}

- Apa Itu Revolusi Industri 4.0 ? Revolusi Industri 4.0 Adalah Prof Klaus Schwab, Ekonomi terkenal dunia asal Jerman, Pendiri dan Ketua Eksekutif World Economic Forum (WEF) yang mengenalkan konsep Revolusi Industri 4.0. Dalam bukunya yang berjudul

"The Fourth Industrial Revolution", Prof Schawab (2017) menjelaskan revolusi industri 4.0 telah mengubah hidup dan kerja manusia secara fundamental. Berbeda dengan revolusi industri sebelumnya, revolusi industri generasi ke-4 ini memiliki skala, ruang lingkup dan kompleksitas yang lebih luas.

- Apa yang mempengaruhi adanya Revolusi Industri 4.0 dalam bidang teknologi?

Revolusi industri 4.0 telah mendorong inovasi-inovasi teknologi yang memberikan dampak disrupsi atau perubahan fundamental terhadap kehidupan masyarakat. Perubahanperubahan tak terduga menjadi fenomena yang akan sering muncul pada era revolusi indutsri 4.0.

Kita menyaksikan pertarungan antara taksi konvensional versus taksi

online atau ojek pangkalan vs ojek online. Publik tidak pernah menduga sebelumnya bahwa ojek/taksi yang populer dimanfaatkan masyarakat untuk kepentingan mobilitas manusia berhasil ditingkatkan kemanfaatannya dengan sistem aplikasi berbasis internet. Dampaknya, publik menjadi lebih mudah untuk mendapatkan layanan transportasi dan bahkan dengan harga yang sangat terjangkau. Yang lebih tidak terduga, layanan ojek online tidak sebatas sebagai alat transportasi alternatif tetapi juga merambah hingga bisnis layanan antar (online delivery order). Dengan kata lain, teknologi online telah

membawa perubahan yang besar terhadap peradaban manusia dan ekonomi.

- Dampak/Peluang dengan adanya revolusi industri 4.0 ?

Revolusi industri 4.0 membuka peluang yang luas bagi siapapun

untuk maju. Teknologi informasi yang semakin mudah terakses hingga ke seluruh pelosok menyebabkan semua orang dapat terhubung didalam sebuah jejaring sosial. Banjir informasi seperti yang diprediksikan Futurolog Alvin Tofler (1970) menjadi realitas yang ditemukan di era 
revolusi industri saat ini. Informasi yang sangat melimpah ini menyediakanmanfaat yang besar untuk pengembangan ilmu pengetahuan maupun perekonomian.

Masyarakat di era revolusi industri 4.0 memiliki

ketergantungan yang sangat besar dalam menggunakan teknologi informasi. Sebuah survey pada tahun 2014 dilakukan oleh Nokia

menemukan temuan-temuan yang mengejutkan mengenai tingkat ketergantungan manusia terhadap teknologi. Pertama, rata-rata hampir setiap enam setengah menit seseorang mengecek ponselnya. Bahkan dalam waktu 16 jam saat orang beraktivitas, mereka melakukan 150 kali per hari untuk memerika ponsel mereka. Kedua, satu dari empat orang mengakui durasi onlinenya lebih banyak daripada durasi tidurnya dalam setiap harinya. Ketiga, 1.500 responden di Inggris menghabiskan waktunya dengan bermedia sosial selama 62 juta jam per hari. Keempat, perempuan lebih sering berselancar di facebook daripada laki-laki. Kelima, tingkat kecanduan terhadap media sosial seperti twitter dan facebook lebih tinggi daripada merokok.

Melalui internet, akses informasi dapat dijangkau hingga ke berbagai penjuru dunia. Fakta ini menjadi

peluang bagi para wirausahawan muda untuk mempromosikan produkproduk kreatifnya hingga ke berbagai belahan dunia.

- Adakah Tantangan yang akan dihadapi pada revolusi industri 4.0 ?

Revolusi industri generasi empat tidak hanya menyediakan peluang, tetapi juga tantangan bagi generasi milineal. Kemajuan ilmu pengetahuandan teknologi sebagai pemicu revolusi indutri juga diikuti dengan implikasi lain seperti pengangguran, kompetisi manusia vs mesin, dan tuntutan kompetensi yang semakin tinggi.

Menurut Prof Dwikorita Karnawati (2017), revolusi industri 4.0 dalam lima tahun mendatang akan menghapus 35 persen jenis pekerjaan. Dan bahkan pada 10 tahun yang akan datang jenis pekerjaan yang akan hilang bertambah menjadi 75 persen. Hal ini disebabkan pekerjaan yang diperankan oleh manusia setahap demi setahap digantikan dengan teknologi digitalisasi program. Dampaknya, proses produksi menjadi lebih cepat dikerjakan dan lebih muda didistribusikan secara masif dengan keterlibatan manusia yang minim. 


\section{E. REFERENCE}

[1] O. M. Febriani and A. S. Putra, "Sistem Informasi Monitoring Inventori Barang Pada Balai Riset Standardisasi Industri Bandar Lampung," J. Inform., vol. 13, no. 1, pp. 90-98, 2014.

[2] A. S. Putra, "Paperplain: Execution Fundamental Create Application With Borland Delphi 7.0 University Of Mitra Indonesia," 2018.

[3] A. S. Putra, "2018 Artikel Struktur Data, Audit Dan Jaringan Komputer," 2018.

[4] A. S. Putra, "ALIAS MANAGER USED IN DATABASE DESKTOP STUDI CASE DB DEMOS."

[5] A. S. Putra, "COMPREHENSIVE SET OF PROFESSIONAL FOR DISTRIBUTE COMPUTING."

[6] A. S. Putra, "DATA ORIENTED RECOGNITION IN BORLAND DELPHI 7.0."

[7] A. S. Putra, "EMBARCADERO DELPHI XE 2 IN GPUPOWERED FIREMONKEY APPLICATION."

[8] A. S. Putra, "HAK ATAS KEKAYAAN INTELEKTUAL DALAM DUNIA TEKNOLOGY BERBASIS REVOLUSI INDUSTRI 4.0."

[9] A. S. Putra, "IMPLEMENTASI PERATURAN PERUNDANGAN UU. NO 31 TAHUN $2000 \quad$ TENTANG DESAIN INDUSTRI BERBASIS INFORMATION TECHNOLOGY."

[10] A. S. Putra,
"IMPLEMENTATION OF PARADOX DBASE."

[11] A

A. S. Putra,
"IMPLEMENTATION

TRADE SECRET CASE

STUDY SAMSUNG MOBILE PHONE."

[12] A. S. Putra, "IMPLEMENTATION PATENT FOR APPLICATION WEB BASED CASE STUDI WWW. PUBLIKLAMPUNG. COM."

[13] A. S. Putra, "IMPLEMENTATION

SYSTEM FIRST TO INVENT IN DIGITALLY INDUSTRY."

[14] A. S. Putra, "MANUAL REPORT \& INTEGRATED DEVELOPMENT

ENVIRONMENT BORLAND DELPHI 7.0."

[15] A. S. Putra, "PATENT AS RELEVAN SUPPORT RESEARCH."

[16] A. S. Putra, "PATENT FOR RESEARCH STUDY CASE OF APPLE. Inc."

[17] A. S. Putra, "PATENT PROTECTION FOR APPLICATION INVENT."

[18] A. S. Putra, "QUICK REPORT IN PROPERTY PROGRAMMING."

[19] A. S. Putra, "REVIEW CIRCUIT LAYOUT COMPONENT

REQUIREMENT ON ASUS NOTEBOOK."

[20] A. S. Putra, "REVIEW TRADEMARK PATENT FOR INDUSTRIAL TECHNOLOGY BASED 4.0."

[21] A. S. Putra, "TOOLBAR COMPONENT PALLETTE IN OBJECT

ORIENTED 
PROGRAMMING."

[22] A. S. Putra, "WORKING

DIRECTORY SET FOR PARADOX 7."

[23] A. S. Putra, "ZQUERY CONNECTION

IMPLEMENTED

PROGRAMMING STUDI CASE PT. BANK BCA Tbk."

[24] A. S. Putra, D. R. Aryanti, and I. Hartati, "Metode SAW (Simple Additive Weighting) sebagai Sistem Pendukung Keputusan Guru Berprestasi (Studi Kasus: SMK Global Surya)," in Prosiding Seminar Nasional Darmajaya, 2018, vol. 1, no. 1, pp. 85-97.

[25] A. S. Putra and O. M. Febriani, "Knowledge Management Online Application in PDAM Lampung Province," in Prosiding International conference on Information Technology and Business (ICITB), 2018, pp. 181-187.
[26] A. S. Putra, O. M. Febriani, and B. Bachry, "Implementasi Genetic Fuzzy System Untuk Mengidentifikasi Hasil Curian Kendaraan Bermotor Di Polda Lampung," SIMADA (Jurnal Sist. Inf. dan Manaj. Basis Data), vol. 1, no. 1, pp. 21-30, 2018.

[27] A. S. Putra, H. Sukri, and K. Zuhri, "Sistem Monitoring Realtime Jaringan Irigasi Desa (JIDES) Dengan Konsep Jaringan Sensor Nirkabel," IJEIS (Indonesian J. Electron. Instrum. Syst., vol. 8, no. 2, pp. 221-232.

[28] D. P. Sari, O. M. Febriani, and A. S. Putra, "Perancangan Sistem Informasi SDM Berprestasi pada SD Global Surya," in Prosiding Seminar Nasional Darmajaya, 2018, vol. 1, no. 1, pp. 289-294. 